Volume 7 No. 2, Juli-Desember 2020

P-ISSN: 2406-808X // E-ISSN: 2550-0686

https://journal.iainlangsa.ac.id/index.php/ikhtibar

https://doi.org/10.32505/ikhtibar.v7i2.615

\title{
KERJASAMA ORANGTUA DAN GURU PAI \\ DALAM MEMOTIVASI SISWA MENGHAFAL AL-QUR'AN
}

\author{
Robi Aksyhari, Sugiatno, Muhammad Taqqiyudin, Amimah Qodari \\ Institut Agama Islam Negeri Curup \\ robbyaksyhari01@gmail.com
}

\begin{abstract}
Abstrak
Penelitian ini bertujuan menemukan gambaran tentang kerjasama orang tua dan guru dalam memberikan motivasi kepada siswa untuk menghafal al-Quran sebagai program SD 05 Kecamatan Bermani Ulu, Rejang Lebong, Bengkulu. Penelitian ini menggunakan pendekatan kualitatif. Data dikumpulkan melalui teknik observasi dan wawacara. Setelah data terkumpul, tahapan selanjutnya adalah pemilahan data, penyajian data dan penarikan kesimpulan. Simpulan yang diperoleh dalam penelitian menunjukkan bahwa bentuk kerja sama Guru SDN 05, Kec. Bermani Ulu, Kab. Rejang Lebong dengan Wali Siswa; menjalin komunikasi satu sama lain, untuk memberikan pengawasan dan bimbingan di rumah, memotivasi siswa dalam bentuk apapun dan bekerja sama mengadakan perlombaan hafalan untuk siswa di sekolah pada hari-hari besar Islam.
\end{abstract}

Kata kunci: Kerjasama, orang tua, guru, motivasi siswa

\section{COOPERATION BETWEEN PARENTS AND PAI TEACHERS IN MOTIVATING STUDENTS TO MEMORIZE AL-QUR'AN}

\begin{abstract}
This study aimed at finding out the portrayal of cooperation between parents and teachers in providing motivation for students to memorize al-Qur'an as a program of SDN 05 in Bermani Ulu district, Rejang Lebong, Bengkulu. This study used a qualitative approach. The data were collected using observation and interview techniques. After the data were collected, the next step was to select the data, present the data, and draw conclusion. The conclusion got based on the study indicated that the form of cooperation between teachers of SDN 05 in Bermani Ulu district, Rejang lebong, and parents was built up in ways of establishing communication with one another, giving guidance and controlling at home, motivating students in every way, and working together to make Qur'an memorization competition for students at school on Islamic big days.
\end{abstract}

Keywords: cooperation, parents, teachers, students' motivation 


\section{Pendahuluan}

Al-Qur'an adalah kalam Allah yang berupa mukjizat yang diturunkan oleh-Nya kepada manusia, melalui Jibril, dengan perantara Rasul terakhir, Muhammad, berfungsi utama sebagaipetunjuk manusia sebagai mahluk psikofisik yang bernilai ibadah ${ }^{1}$. Salah satu di antara banyak keistimewaan al-Qur'an adalah ia merupakan kitab yang dijelaskan dan dimudahkan untuk dihafal ${ }^{2}$.

Al-Qur'an memperkenalkan dirinya dengan berbagai ciri dan sifat, satu diantaranya adalah bahwa ia merupakan kitab yang keotentikannya dijamin oleh Allah dan dipelihara ${ }^{3}$. Kitab suci umat Islam ini adalah satu-satunya kitab suci samawi yang masih murni dan asli. Tidak seperti kitab suci sebelumnya, seperti kitab Taurat dan Injil yang telah mengalami "tahrif" atau perubahan baik dari segi redaksi maupun dari segi makna ${ }^{4}$. Perubahan terhadap kitab suci ini baik dari segi arti maupun dari segi redaksi menyebabkan implikasi yang serius dalam kehidupan keagamaan.

Jadi, jika Al-Qur'an yang ada sekarang ini masih asli dan murni sesuai dengan apa yang diajarkan oleh Nabi Muhammad SAW kepada para sahabatnya, hal itu karena Allah yang menjaganya.

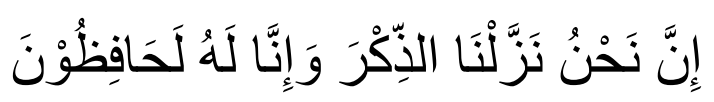

Sesungguhnya kamilah yang menurunkan Al-Qur'an, dansesungguhnya kami benarbenar memeliharanya" (QS. Al-Hijr: 9).

Menghafal al-Qur'an adalah salah satu cara untuk memelihara kemurnian al-Qur'an. Oleh karena itu beruntunglah orang-orang yang dapat menjaga al-Qur'an dengan menghafal, memahami dan mengamalkan kandungannya ${ }^{5}$. Dengan al-Qur'an, Allah mengangkat derajat para penghafal al-Qur'an serta memakaikan kedua orangtuanya mahkota, yang sinarnya lebih terang dari pada sinar matahari'. "Barang siapa yang membaca al-Qur'an dan mengamalkanya

${ }^{1}$ Noza Aflisia, "Urgensi Bahasa Arab Bagi Hafizh Al-Qur'an,” FOKUS Jurnal Kajian Keislaman Dan Kemasyarakatan 1, no. 1 (2016): 47-66.

${ }^{2}$ Nurkhaeriyah Nurkhaeriyah, "Metode Menghafal Al-Qur'an pada Anak Usia Dini di Rumah Tahfidz Qur'an At-Taqwa Kota Cirebon,” Jurnal Jendela Bunda Program Studi PG-PAUD Universitas Muhammadiyah Cirebon 7, no. 1 (2019): 1-16; Besse Tantri Eka, "Penerapan Metode Jibril Dalam Meningkatkan Kemampuan Menghafal Qs. al-Insyiqoq ayat 1-25 di Ma'had Al-Jami'ah UIN Raden Fatah Palembang (Skripsi)" (PhD Thesis, UIN Raden Fatah Palembang, 2016); Akmal Mundiri and Irma Zahra, "Implementasi Metode STIFIn Dalam Meningkatkan Kemampuan Menghafal Al-Qur'an Di Rumah Qur'an STIFIn Paiton Probolinggo," Jurnal Pendidikan Agama Islam (Journal of Islamic Education Studies) 5, no. 2 (2017): 201-223; H. Suwito, "Sistem Menghafal Cepat Al-Quran 40 Hari untuk 30 Juz (Studi Di Ma'had Tahfidz al-Quran Di Dawuhan Purbalingga)," 2016.

3 Cahaya Khaeroni, "Sejarah Al-Qur'an (Uraian Analitis, Kronologis, Dan Naratif Tentang Sejarah Kodifikasi Al-Qur'an)," HISTORIA: Jurnal Program Studi Pendidikan Sejarah 5, no. 2 (2017): 195-206; Muhammad Iqbal Ansari, "Pelaksanaan Karantina Tahfidzh Al-Qur'an 30 Hari Untuk Siswa Sekolah Dasar Dan Madrasah Ibtidaiyah Di Banjarmasin," Muallimuna: Jurnal Madrasah Ibtidaiyah 2, no. 2 (2017): 1-18; Hasan Zaini, "Perspektif Alquran Tentang Peningkatan Etos Kerja dalam Menghadapi Revolusi Industri 4.0 Dan Perubahan Sosial 5.0," PROCEEDING IAIN Batusangkar 1, no. 1 (2020): 1-18.

${ }^{4}$ Nurma Zunita, "Implementasi Adab Hamalatul Qur'an Dalam Kitab at-Tibyan Karya Imam an-Nawawi Di Ponpes Nurul Qur'an Kajen Margoyoso Pati” (PhD Thesis, UIN Walisongo Semarang, 2018).

${ }^{5}$ Eva Apriyanti and Hasan Basri, "Pembiasaan Membaca Al-Qur'an Di Pondok Al-Ishlah Sendangagung Paciran Lamongan," Tamaddun 21, no. 1 (2020): 053-066.

${ }^{6}$ Maryam Kasim, "Peningkatan Hasil Belajar Mengartikan Surat-Surat Pendek Melalui Metode Card Sort Mapel Qur'an-Hadits Siswa Kelas V SD Muhammadiyah 16 Semarang Tahun Pelajaran 2015-2016" (PhD Thesis, UIN Walisongo, 2016); Adi Haironi, ArI Anshori, and M. Ag Muthoifin, "Implementasi Metode Tahfizụul Quran Abaq, Sabqi, Manzil Di Marhalah Mutawasithah Dan Tsanawiyah Putri Pondok Pesantren Imam Bukhari Tahun Pelajaran 2010-2014" (PhD Thesis, Universitas Muhammadiyah Surakarta, 2016); MELISA PAULINA, "Regulasi Diri Mahasiswa UIN Raden Fatah Penghafal Al-Qur'an Di Rumah Tahfidz Yatim Dhuafa Palembang.(Skripsi*)” (PhD Thesis, UIN Raden Fatah Palembang, 2020). 
maka akan dipakaikan kepada kedua orang tuanya mahkota yang sinarnya lebih terang dari pada sinar matahari di dunia pada hari kiamat nanti, kalaulah sekiranva ada bersama kalian, maka apa perkiraan kalian tentang orang yang mengamalkannya (al-Qur'an)?"7

Ajaklah anak untuk berdialog yang intinya adalah untuk meyakinkannya tentang pentingnya al-Qur'an baik di dunia maupun di akhirat dan juga keutamaan orang yang membaca al-Qur'an dibandingkan orang yang tidak membacanya ${ }^{8}$. Kemudianyakinkan juga dengan hadits-hadits yang memotivasi untuk belajar al-Qur'an. Semisal hadits Rasulullah SAW, yang berbunyi:

"Sebaik-baik kalian adalah orang yang mempelajari al-Qur'an dan mengajarkannya".(HR. Bukhari).

Bersamaan dengan itu pula mulai tumbuh potensi-potensi anak yang dapat digunakan untuk berinteraksi dengan al-Qur'an. Namun, seorang pendidik tetap harus berusaha sekuat tenaga untuk menanamkan al-Qur'an pada hati anak didiknya dengan baik ${ }^{9}$. Untuk mendukung anak menghafal al-Qur'an, orang tua bisa memasukkan mereka di tempat Tahfidz al-Qur'an yang bagus dan kalau bisa yang dekat dengan rumah sejak dini. Dalam usia normal, fikiran anak usia Sekolah Dasar ini berkembang secara berangsur-angsur dan secara tenang. Anak betul-betul berada dalam stadium belajar ${ }^{10}$. Disamping lingkungan sekolah memberikan pengaruh yang sistematis terhadap pembentukan akal budi anak ${ }^{11}$. Melalui proses pembelajaran al-Qur'an di sekolah tentu membuat siswa yang berpengetahuan yng secara kontinui bertambah secara pesat ${ }^{12}$.

Kemampuan anak untuk menghafal dimulai sejak kecil, yaitu saat anak mulai belajar berbicara dan menguasainya dengan baik, setelah usia tiga tahun ${ }^{13}$. Kemampuan untuk menghafal itu berbeda antara anak yang satu dengan yang lainnya ${ }^{14}$. Namun yang terpenting

7 (HR. Ahmad, Abu Daud, al-Baihaqi dan al-Hakim dalam Sunan Abu Dawud, hal, 246, hadits no. 1241, juz 4)

${ }^{8}$ Rohimah Nasaiah, 'Proses Pelaksanaan Pembelajaran Tahfiz Al-Qur'an di Pondok Pesantren Al-Qur'an Harsallakum Kota Bengkulu” (PhD Thesis, IAIN Bengkulu, 2019).

${ }^{9}$ Hartono Hartono, "Pendidikan Karakter Dalam Al Qur'an Pada Kalangan Remaja Di Era Digital," AlBayan: Jurnal Ilmu al-Qur'an Dan Hadist 1, no. 2 (2018): 178-199; Duma Mayasari, "Internalisasi Nilai-Nilai Karakter Peserta Didik Dalam Pembelajaran Tahsin Dan Tahfidz Al-Qur'an di MA Tahfizhil Qur'an Yayasan Islamic Centre Sumatera Utara," ANSIRU PAI: Pengembangan Profesi Guru Pendidikan Agama Islam 3, no. 2 (2019): 40-48.

10 Abdurrahman Abdurahman, "Kesadaran Beragama Pada Anak," Jurnal Al-Irsyad: Jurnal Bimbingan Konseling Islam 1, no. 1 (2019): 56-68.

11 nadri Taja, Dinar Nur Inten, And Arif Hakim, "Upaya Meningkatkan Keterampilan Mengajar Baca Tulis Al-Quran Bagi Guru," Jurnal Obsesi: Jurnal Pendidikan Anak Usia Dini 3, No. 1 (2019): 68-81; Mirzon Daheri And Idi Warsah, "Pendidikan Akhlak: Relasi Antara Sekolah Dengan Keluarga," At-Turats: Jurnal Pemikiran Pendidikan Islam 13, No. 2 (2019): 1-20; Sabar Budi Raharjo, "Pendidikan Karakter Sebagai Upaya Menciptakan Akhlak Mulia," Jurnal Pendidikan Dan Kebudayaan 16, No. 3 (2010): 229-38, Https://Doi.Org/10.24832/Jpnk.V16i3.456; Wasis Ridwan And Ode Moh Man Arfa Ladamay, "Peran Guru Pendidikan Agama Islam Dalam Pembinaan Akhlakul Karimah Peserta Didik di SMA Muhammadiyah 8 Cerme Gresik," Tamaddun 21, no. 1 (April 4, 2020): 067-076, https://doi.org/10.30587/tamaddun.v21i1.1378.

12 zainal Efendi Hasibuan, "Spiritualisasi Pembelajaran dalam Perspektif Islam: Membangun Bangsa Berkarakter Di Tengah Krisis Moral Melalui Spritualisasi Pembelajaran Dalam Perspektif Islam," Darul Ilmi 4, no. 1 (2016).

${ }^{13}$ Aida Hidayah, "Metode Tahfidz Al-Qur'an Untuk Anak Usia Dini (Kajian Atas Buku Rahasia Sukses 3 Hafizh Quran Cilik Mengguncang Dunia),’ Jurnal Studi Ilmu-Ilmu Al-Qur'an Dan Hadis 18, no. 1 (2018): 5170 .

14 Khoirul Anwar and Mufti Hafiyana, "Implementasi Metode ODOA (One Day One Ayat) Dalam Meningkatkan Kemampuan Menghafal Al-Quran,” Jurnal Pendidikan Islam Indonesia 2, no. 2 (2018): 181-198; Yuni Retnowati, "Metode Pembelajaran Hafalan Surat-Surat Pendek Pada Anak Usia Dini RA Full Day SeKabupaten Bantul," Al-Athfal: Jurnal Pendidikan Anak 5, no. 1 (2019): 101-116; Cucu Susianti, "Efektivitas 
adalah memulai, merutinkan, bersikap sabar, serta mencari pahala. Ingatan anak pada usia 612 tahun ini mencapai intensitas paling besar, dan paling kuat. Daya menghafal dan daya memorisasi adalah paling kuat. Anak mampu memuat jumlah materi ingatan paling banyak ${ }^{15}$.

Badwilan dalam Badruzaman menjelelaskan bahwa gagi orang yang niatnya tulus untuk mencari keridhaan Allah dan ketinggian kedudukan dalam surga, maka mereka akan membiasakan anak-anaknya untuk menghafal Al-Qur'an dari semenjak kecil karena adanya kemudahan pada waktu itu dan sebelum bertumpuk-tumpuk kegiatan-kegiatan lain yang menghambat si anak untuk melakukan hal ini ${ }^{16}$. Konon, ada satu perkataan, "menghafal di waktu kecil laksana mengukir di alas batu".

Observasi awal yang dilakukan di SDN 05, Kec. Bermani, Curup, Kab. Rejang Lebong, diperoleh bahwa sekolah ini merupakan salah satu sekolah dasar negeri yang mayoritasi umur siswanya 6-12 tahun, dan memperoleh keterangan bahwa Guru PAI sudah melatih bagaimana menghafal al-Qur'an (surat-surat pendek) yang tujuannya adalah membangun generasi yang hafal al-Qur'an (membentuk penerus penghafal al-Qur'an yang di mulai sejak dini). Jika semangat menghafal al-Qur'an telah tertanam dalam diri setiap anak, maka al-Qur'an secara tidak langsung akan berpengaruh terhadap perilaku mereka. Secara tidak disadari para siswa akan menjaga perilaku dalam aktivitas sehari-hari dengan etika yang baik sebagaimana diajarkan dalam al-Qur'an tersebut (Wawancara, 19 Februari 2020).

Salah satu aspek yang bisa berpengaruh terhadap kedisiplinan anak dalam menghafal adalah dengan adanya metode dan sistem pengajaran yang disesuaikan dengan kemampuan siswa, serta kerja sama yang baik dan saling mendukung antara orangtua dan guru PAI di sekolah. Kerjasama dimaksud adalah sinergitas antara guru dan orang tua dalam memotivasi anak mereka mengikuti program sekolah menghafal surat-surat pendek dalam al-Quran. Jadi, penelitian ini terfokus pada permasalah tentang bentuk kerjasama orangtua dan guru PAI dalam memberikan motivasi agar siswa kelas V SDN 05, Kec. Bermani, Curup, Kab. Rejang Lebong, menghafal ayat-ayat al-Qur'an dalam yang terdapat dalam Juz 30.

\section{Metode Penelitian}

Penelitian ini menggunakan pendekatan kualitatif dimaksudkan sebagai jenis penelitian yang temuan-temuannya tidak diperoleh melalui prosedur statistik atau bentuk hitungan lainnya ${ }^{17}$. Metode kualitatif ini digunakan karena beberapa pertimbangan Pertama, menyesuaikan metode kualitatif lebih mudah apabila berhadapan dengan kenyataan jamak. Kedua, metode ini menyajikan secara langsung hakikat hubungan antara peneliti dan informan. Ketiga, metode ini lebih peka dan lebih dapat menyesuaikan diri dengan banyak penajaman pengaruh bersama terhadap pola-pola nilai yang dihadapi ${ }^{18}$. Dalam hal ini menelusuri fenomena dan memperoleh data dari lapangan sehubungan dengan proses pembelajaran dan kerjasama antara orangtua dan guru dalam meningkatkan motivasi siswa di SDN 05, Kec. Bermani, Curup, Kab. Rejang Lebong.

Data penelitian ini diperoleh dengan menggunakan observasi dan wawancara. Metode ini digunakan untuk mengamati secara langsung terhadap proses pembelajaran pendidikan

Metode Talaqqi Dalam Meningkatkan Kemampuan Menghafal Al-Qur'an Anak Usia Dini," Tunas Siliwangi: Jurnal Program Studi Pendidikan Guru PAUD STKIP Siliwangi Bandung 2, no. 1 (2017): 1-19.

15 Yulia Widji Astuti, "Gambaran Kebiasaan Menyikat Gigi Dan Indeks Ohi-S Pada Siswa Sekolah Dasar," Jurnal Teknologi Keperawatan 2, no. 1 (2019): 1-33; Amalia R. Pautina, “Aplikasi Teori Gestalt Dalam Mengatasi Kesulitan Belajar Pada Anak," Tadbir: Jurnal Manajemen Pendidikan Islam 6, no. 1 (2018): 14-28.

16 Dudi Badruzaman, "Metode Tahfidz Al-Qur'an di Pondok Pesantren Miftahul Huda Ii Kabupaten Ciamis," Idea : Jurnal Humaniora 0, no. 0 (October 22, 2019): 245-53, https://doi.org/10.29313/idea.v0i0.4888.

${ }^{17}$ Albi Anggito Setiawan Johan, Metodologi penelitian kualitatif (CV Jejak (Jejak Publisher), 2018).

18 I. Wayan Suwendra, Metodologi Penelitian Kualitatif Dalam Ilmu Sosial, Pendidikan, Kebudayaan Dan Keagamaan (Nilacakra, 2018); Dedi Supriadi, "Pokoknya Kualitatif: Dasar-Dasar Merancang Dan Melakukan Penelitian Kualitatif," Jakarta: PT. Dunia Pustaka Jaya, 2011; Lexi J. Moleong, Methodology of Qualitative Research (Bandung: Remaja Rosda Karya, 2010). 
Agama Islam terutama pemberian tugas menghafal surat-surat pendek. Adapun tehnik wawancara yang akan digunakan dalam penelitian ini adalah wawancara terstruktur, yaitu bila peneliti atau pengumpul data telah mengetahui dengan pasti tentang informasi apa yang akan diperoleh ${ }^{19}$. Dalam hal ini penulis mengadakan wawancara dengan Kepala Sekolah, guna mendapatkan informasi tentang segala hal yang berkaitan dengan pemanfaatan sarana dan prasarana pendidikan. Selanjutnya penulis melakukan wawancara kepada wali murid, Guru PAI dan Kepala Sekolah menyangkut tentang proses pembelajaran PAI terutama pada pembinaan hafalan al-Qur'an di sekolah.

Analisis data ini digunakan untuk menyusun, menggolah, dan menghubungkan semua data yang diperoleh dari lapangan sehingga menjadi sebuah kesimpulan atau teori. Dalam analisis data dilakukan pengecekan data yang berasal dari wawancara dengan wali murid, Guru PAI dan pihak lain yang berkaitan. Analisis data yang dilakukan akan melalui beberapa tahapan: Data Reduction (Reduksi Data), Data Display (penyajian data), dan penarikan kesimpulan ${ }^{20}$ yang memuat jawaban tentang gambaran kerjasama antar orang tua dengan guru dalam memberikan motivasi kepada siswa. SDN 05, Kec. Bermani, Curup, Kab. Rejang Lebong dalam menghafal al-Qur'an.

\section{Hasil dan Pembahasan}

1. Hasil penelitian

a. Gambaran proses pembelajaran hafalan al-Qur'an di SDN 05, Kec. Bermani, Curup, Kab. Rejang Lebong

Apakah menghafal surat-surat pendek merupakan program yang diwajibkan di sekolah SDN 05, Kec. Bermani, Curup, Kab. Rejang Lebong? Tidak, tapi hanya himbauan dari kepala sekolah, namun kami tekankan bagi siswa yang sudah kelas I ke atas. Jadi pada anak kami kelas $\mathrm{V}$ ini programnya mereka menghafal 5 surat, wadduha, alam nasrah, al-Qadr, zalzalah dan al-Qari'ah saja ${ }^{21}$.

Bagaimana cara guru memotivasi siswa untuk menghafal al-Qur'an? Tanggapan bapak Kohir Nadi antara lain: Kami memberikan nilai yang bagus pada pelajaran PAI bagi yang hafal sesuai dengan target yang kami tetapkan, memberikan hadiah seperti al-Qur'an dan alatalat tulis, supaya siswa kami dalam menghafalkan al-Qur'an lebih semangat dan meberikan motivasi kepada siswa lain yang kurang semangat dalam menghafal surat-surat yang kami berikan, Bahkan mengadakan lomba pada hari besar Islam di sekolah ${ }^{22}$.

Peneliti juga menanyakan "Apakah setiap pertemuan siswa diwajibkan memberikan setoran hafalan kepada guru?" Iya, pada saat istirahat kalau mereka sempat kami persilahkan untuk setoran hafalan. Bahkan sebelum belajar dimulai kami meminta siswa untuk membaca bersama-sama di kelas hafalan mereka. Hal ini agar mereka tidak mudah lupa ayat-ayat yang mereka telah hafalkan dan membantu melancarkan siswa-siswa yang belum begitu hafal ${ }^{23}$.

Sementara itu juga perlu ditanyakan kepada informan tentang "surat-surat apa saja yang wajib dihafal oleh siswa?" Menurut infomasi yang diberikan bapak Kohir Nadi: Kami mendorong siswa menghafal surat an-Nas sampai wadduha. Kami juga menentukan, pada surat-surat awal hanya untuk kelas I-IV, anak kelas V menghafalkan cuma ayat yang kami pilih saja dan khusus anak kelas VI kami fokuskan belajar umtuk menghadapi Ujian

${ }^{19}$ Kathryn Roulston, “Analysing Interviews,” The SAGE Handbook of Qualitative Data Analysis, 2014, $297-312$.

${ }^{20}$ Matthew B. Miles, A. Michael Huberman, and Johnny Saldaña, Qualitative Data Analysis: A Methods Sourcebook. 3rd (Thousand Oaks, CA: Sage, 2014).

${ }^{21}$ Wawancara dengan guru PAI bapak Kohir Nadi, 19 Februari 2020

${ }^{22}$ Wawancara, 19 Februari 2020

${ }^{23}$ Wawancara, 19 Februari 2020 
Nasional ${ }^{24}$. Pertanyaan selanjutnya adalah "Bagaimana cara guru menuntun siswa dalam menghafal surat-surat pendek dalam al-Qur'an?"

Kami membacakan ayatnya terlebih dahulu kemudian siswa mengikuti bacaan kami berulang-ulang, atau kalau dalam dalam metode manghafal dikenal dengan metode mendengarkan. Kami juga meminta siswa sering mendengarkan bacaan ayat-ayat pendek tersebut dengan menggunakan media HP, seperti youtube, mp3 dan lainlainnya kalau ada di rumah. Karena sekarang mayoritas orang tua menggunakan HP android. Jadi bisa diulang-ulang sambil mendengar bacaan dari hp tersebut. Kami juga memberitahu kepada orang tua untuk mendampingi siswa dalam menghafal surat-surat yang kami berikan, agar tidak disalahgunakan oleh siswa di rumah ${ }^{25}$.

Berdasarkan informasi yang diperoleh di atas, tergambar bahwa hafalan al-Qur'an di SDN 05, Kec. Bermani, Curup, Kab. Rejang Lebong merupakan program penungjang yang menjadi himbauan pihak sekolah, khusus pada siswa kelas I sampai dengan kelas V. Adapun pelaksanaan program tersebut diserahkan kepada guru PAI SDN 05, Kec. Bermani, Curup, Kab. Rejang Lebong dengan menjalin kerjasama dengan wali murid. Sementara bagi kelas V hanya dibebankan lima surat saja, yaitu adduha, lam nasrah, al-Qadr, zalzalah dan al-Qari'ah. Metode yang digunakan oleh guru PAI dalam membimbing siswa adalahah metode istima' atau mendengarkan, yaitu mendengarkan guru membaca terlebih dahulu kemudian siswa mengikuti bacaan tersebut berulang-ulang.

\section{b. Gambaran bentuk kerja sama antara orangtua dan guru PAI dalam memotivasi anak dalam menghafal al-Qur'an.}

Pada tujuan penelitian yang kedua ini, peneliti ingin lebih jauh mengetahui bagaimana bentuk kerja sama antara guru atau pihak sekolah dan wali siswa dalam memotivasi anak mereka untuk gemar mengafal al-Qur'an. Pertanyaan-pertanyaan tersebut antara lain adalah: Bagaimana tanggapan wali murid terhadap program menghafal di sekolah? Menurut bapak Kohir Nadi selaku guru PAI menyatakan bahwa: "Sejauh ini tanggapan orang tua/wali murid postif terhadap terlakasanya program hafalan ini, mereka sangat senang kalau anak-anak mereka gemar membaca dan menghafal al-Qur'an, dan orang tua murid juga bisa membantu anak-anak mereka dalam mengahafal surat-surat yang diberikan ${ }^{26}$.

Hal ini senada dengan informasi yang disampaikan oleh beberapa wali siswa yang temui oleh peneliti di rumah mereka yang berada di lingkungan sekolah antara lain:

Saya sangat setuju dengan penerapan program sekolah tentang kewajiban menghafal surat-surat pendek, terusterang ada sebagian dari kami merasa membebani anak mereka. Namun setelah mengahdiri pertemuan/musyawarah tentang program penerapan kewajiban menghafal surat-surat pendek, yah kami pandang positif, dan kami sebagai orang tua menyambut baik program tambahan hafalan ayat-ayat pendek di sekolah. Kami banggalah kalau anak kami sudah bisa membaca al-Qur'an dan ada yang hafal juga. Maka kami juga mekaksanakan pengasawasan ketika ibu guru meminta bantuan kepada kami untuk mengawasi dan memasukkan anak kami ke tempat guru ngaji dan mengingatkan anak kami untuk menghafal kembali di rumah ${ }^{27}$.

Pertanyaan berikutnya adalah" apakah guru meminta wali murid untuk memberikan motivasi kepada anak-anak mereka untuk menghafal di rumah?" Menurut tanggapan guru PAI SDN 05, Kec. Bermani, Curup, Kab. Rejang Lebong:

\footnotetext{
${ }^{24}$ Wawancara, 19 Februari 2020

${ }^{25}$ Wawancara, 21 Februari 2020

${ }^{26}$ Wawancara, 21 Februari 2020

${ }^{27}$ Wawancara, 22 Februari 2020
} 
Kalau ditanya tentang hal itu, iya pak, inilah salah satu bentuk kerja sama kami dengan orang tua dalam melaksakan program menghafal ini. kami meminta kepada seluruh wali siswa kelas I-V dengan mengundang mereka ke sekolah untuk memberikan motivasi agar anak-anak mereka semangat menghafal ayat-ayat pendek di rumah dan jangan merasa terbebani. Alhamdulillah sebagaian wali siswa memenuhi undangan kami, dan berkomitmen untuk membantu kami dalam memotivasi anak-anak mereka ${ }^{28}$.

Pertanyaan yang sama juga kami tanyakan kepada wali yang sempat kami temui di rumah mereka menyatakan bahwa:

Waktu itu bapak adok (nama panggilan guru PAI), mengundang kami untuk ke sekolah bu. Ternyata undangan tersebut menjelaskan tentang program menghafal di sekolah. Memang bapak adok meminta kami untuk memotivasi anak kami, iyah waktu itu saya diundang oleh bapak guru PAI atas mana kepala sekolah SDN 05, tapi lupa saya tepat harinya kapan, karena sudah cukup lama, tujuannya untuk meminta kami mengasawi anak-anak di rumah agar semangat menghafal ayat-ayat pendek ${ }^{29}$.

Pertanyaan selanjutnya adalah: "Apakah guru meminta wali murid agar mengkoreksi hafalan anak mereka di rumah?" iya (kata guru PAI), kami sangat menekankan kepada wali siswa disamping memotivasi anak-anak mereka, juga agar berkesempatan untuk koreksi hafalan mereka ${ }^{30}$. Memang kami beberapa kali dihubungi oleh bapak kohir nadi untuk mengkoreksi hafalan anak-anak. Bapaknya yang sering mennyimak dan mengkoreksi kalau seandainya salah, ditambah lagi dari salah satu awali murid; "Iya betul itu, cuma kami terusterang menyerahkan kepada guru ngaji di masjid dan memesan kepada guru ngaji untuk membenarkan hafalan anak-anak kami, dan saya juga menyempatkan waktu untuk meminta anak membaca hafalannya dan saya menyimak, itu biasanya habis magrib saya lakukan sesudah sholat magrib. Tapi ya tidak tiap magrib, itu kalau mereka tidak ke masjid ngaji di sana $^{31}$.

Pertanyaan selanjutnya adalah: Apa saja bentuk-bentuk motivasi yang diberikan oleh wali siswa ketika anak hafal ayat-ayat pendek? Tanggapan wali siswa, antara lain: Bentuk motivasi kami, seperti memuji mereka dek, atau memberikan hadiah seperti peci baru kalau hafal sampai surat duha misalnya. Dan salah satu dari wali siswa menggungkapan "kalau kami tidak menjanjikan apapun kepada anak kami. Cuma kami sampaikan kepada mereka "nak kalau kamu hafal ayat-ayat pendek kami bisa mengimami kami kalau kamu sudah besar". Jadi mereka semangat dek ${ }^{32}$.

Begitu juga halnya dengan salah satu wali siswa, Nah kalau cara kami memotivasi anak-anak kami agar mereka semangat menghafal ayat-ayat pendek, kami sampaikan pada anak kami kalau kamu hafal ayat pendek, jika ada lomba di masjid pada hari besar bisa mendaftarkan diri, jika kamu menang maka ibu/bapak akan belikan baju baru dan membuat kami bangga kepadamu ${ }^{33}$.

Oleh karena itu pertanyaan terakhir untuk memperloleh informasi tentang bentukbentuk kerjasama guru PAI dan orang tua dalam membina siswa menghafal surat-surat pendek adalah "apakah guru dan wali murid pernah bekerja sama membuat perlombaan hafalan di sekolah? Menurut infromasi guru PAI mengenai pertanyaan ini adalah: Pernah (ujar guru PAI), baru satu kali kami melibatkan wali siswa untuk berpartisifasi dalam

\footnotetext{
${ }^{28}$ Wawancara, 22 Februari 2020

${ }^{29}$ Wawancara, 22 Februari 2020

${ }^{30}$ Wawancara, 22 Februari 2020

${ }^{31}$ Wawancara, 22 Februari 2020

${ }^{32}$ Wawancara, 22 Februari 2020

${ }^{33}$ Wawancara, 22 Februari 2020
} 
perlombaan di sekolah, termasuh tangkai perlombaan tersebut menghafal ayat-ayat pendek pada siswa kelas I sampai kelas III, waktu peringatan Maulid Nabi tahun $2019^{34}$.

Informasi yang telah disajkan di atas, menunjukkan bahwa terdapat beberapa bentuk kerja sama yang dilakukan oleh guru PAI dengan orang tua siswa, mulai dari menjalin komunikasi dengan wali siswa untuk memberikan pengawasan dan meminta kepada wali untuk membantu membimbing di rumah, menghimbau kepada wali untuk memberikan motivasi dalam bentuk pujian, hadiah dan lain-lain, serta mengadakan perlombaan di sekolah bersama wali siswa.

\section{c. Kendala yang dihadapi siswa dalam menghafal al-Quran.}

Dalam observasi selanjutnya, fokus peneliti kali ini ingin melihat dan menemukan kendala yang ditemui oleh guru PAI dalam meksanakan pembelajaran PAI teutama program menghafal surat pendek dalam al-Qur'an, pertama yang kami akan lihat adalah gambaran kemampuan siswa dalam membaca al-Qur'an? Untuk menemukan jawaban tentang hal tersebut, peneliti meminta izin kepada kepala sekolah dan guru PAI untuk melihat langsung kemampuan siswa dalam menghafal dan ayat-ayat apa saja yang mereka sudah hafalkan. Ketika melakukan observasi ini, peneliti melakukan test langsung guna melihat kemampuan dari beberapa siswa kelas I-III SDN 05, Kec. Bermani, Curup, Kab. Rejang Lebong, satu persatu. Dari 18 siswa hanya 3 (tiga) siswa yang belum tuntas hafalannya sesusai dengan target yang diberikan oleh guru dari surat al-Qariah sampai ad-Duha. Keterangan dari bapak Kohir Nadi selaku guru PAI: "Beberapa siswa yang belum hafal tersebut memang tergolong siswa yang lambat menghafal. Hal ini disebabkan mereka belum begitu lancar membaca alQur'an, kami sudah meminta orang tua mereka untuk membantu kami membimbing mereka di rumah, dan meminta mereka mengaji di masjid dengan guru ngaji yang ada di t4 mereka tinggal" 35 .

Dengan demikian, peneliti kembali mewawancarai guru PAI dengan pertanyaan selanjutnya Apakah siswa merasa terbebani oleh hafalan ayat-ayat pendek di sekolah? Tanggapan guru PAI: "Memang pertama kali kepala sekolah meminta kami untuk memprogramkan hafalan ayat-ayat pendek, siswa kami agak merasa berat dan terbebani. Namun kami terus memotivasi mereka bahwa menghafal ayat-ayat pendek itu tidak sulit yang penting ada kesungguhan"36

Apakah waktu pelajaran PAI cukup untuk memberikan tuntunan menghafal kepada siswa? Kendala yang kami temui dalam melaksanakan program menghafal ayat-ayat pendek di SDN 05, Kec. Bermani, Curup, Kab. Rejang Lebong antara lain adalah waktu pembelajaran yang sempit. Sehingga kami meminta kepada kepala sekolah, dan guru-guru lain untuk membantu kami memberikan waktu untuk membiasakan kepada siswa, sebelum pelajaran dimulai pada pagi hari, siswa diminta untuk bersama-sama membaca ayat yang telah dihafalkan oleh mereka, ini salah satu cara agar mereka dapat menjaga hafalan mereka ${ }^{37}$.

Untuk melengakapi data tentang kendala yang dihadapi dalam program menghafal ayat-ayat pendek al-Qur'an ini, peneliti perlu menanyakan "apakah seluruh wali murid memberikan dukungan terhadap program hafalan di sekolah?" Menurut pendapat guru PAI SDN 05, Kec. Bermani, Curup, Kab. Rejang Lebong:

"Seperti yang telah saya sampaikan bahwa antusias orang tua murid menangggapi program ini cukup tinggi, namun karena latar belakang pekerjaan orang tua berbedabeda dan tingkat pendidikan orang tua juga bervariasi, tentu perhatian orang tua terhadap anak mereka di rumah juga berbeda-beda. Maka kami selalu manjalin komunikasi untuk memberikan perhatian kepada anak mereka di rumah agar

\footnotetext{
${ }^{34}$ Wawancara, 22 Februari 2020

${ }^{35}$ Wawancara, 24 Februari 2020

${ }^{36}$ Wawancara, 24 Februari 2020

${ }^{37}$ Wawancara, 24 Februari 2020
} 
membiasakan mengulang hafalannya yang sudah dihafalkan di sekolah. Karena tanpa dukungan melalui perhatian orang tua di rumah tentu hafalan mereka cepat hilang"38.

Berdasarkan hasil wawancara yang telah dipaparkan tadi, ditemukan informasi tentang kendala apa saja yang ditemui oleh guru dalam membimbing para siswa dalam menghafal alQur'an antara lain; kurangnya waktu belajar PAI jika hanya mengandalkan waktu tersebut, jadi guru meminta kepada kepala sekolah dan guru, sebelum memulai pelajaran, anak-anak diminta untuk membaca ayat-ayat yang telah dihafal bersama-sama. Guru juga meminta kepada kepala sekolah untuk menambah jam belajar di luar jam pelajaran PAI, karena program ini sifatnya ekstrakulikuler. Kendala selanjutnya adalah masih kurangnya perhatian orang tua di rumah. Hal ini dikarena, profesi orang tua dan tingkat pendidikan mereka berbeda-beda, sehingga hal ini berdampak pada perhatian mereka dan respon mereka terhadap program hafalan di sekolah tersebut meskipun guru PAI dan wali siswa telah melakukan komunikasi dan menjalin kerjasama.

\section{Pembahasan}

Al-Qur'an menurut istilah adalah kitab yang diturunkan kepada Rasulullah saw, ditulis dalam mushaf, dan diriwayatkan secara mutawatir tanpa keraguan ${ }^{39}$. Setelah melihat definisi menghafal dan Al-Qur'an di atas dapat disimpulkan bahwa Tahfidz Al-Qur'an adalah proses untuk memelihara, menjaga dan melestarikan kemurnian Al-Qur'an yang diturunkan kepada Rasulullah SAW di luar kepala agar tidak terjadi perubahan dan pemalsuan serta dapat menjaga dari kelupaan baik secara keseluruhan maupun sebagiannya.

Sedangkan program pendidikan menghafal Al-Qur'an adalah program menghafal AlQur'an dengan mutqin (hafalan yang kuat) terhadap lafazh-lafazh Al-Qur'an dan menghafal makna-maknanya dengan kuat yang memudahkan untuk menghindarkannya setiap menghadapi berbagai masalah kehidupan, yang mana Al-Qur'an senantiasa ada dan hidup di dalam hati sepanjang waktu sehingga memudahkan untuk menerapkan dan mengamalkannya 40. Menghafal al-Qur'an adalah pekerjaan yang sangat mulia ${ }^{41}$. Akan tetapi menghafal alQur'an tidaklah mudah seperti membalikan telapak tangan, oleh karena itu ada hal-hal yang perlu dipersiapkan sebelum menghafal agar dalam proses menghafal tidak begitu berat. Di antara beberapa hal yang harus terpenuhi sebelum seseorang memasuki periode menghafal alQur'an ialah Menurut Wahid dalam Oktapiayani; Khozin; Rahmi; dan Hendrawati ${ }^{42}$ :

\footnotetext{
${ }^{38}$ Wawancara, 24 Februari 2020

39 Aida Imtihana, "Implementasi Metode Jibril Dalam Pelaksanaan Hafalan Al-Qur'an Di SD Islam Terpadu Ar-Ridho Palembang," Tadrib 2, no. 2 (2016): 179-197.

${ }^{40}$ Joko Wiyono, "Efektivitas Metode Kaidah Daqu di Pendidikan Hafiz SD Daarul Qur'an Semarang" (PhD Thesis, UNNES, 2019).

41 jamil abdul aziz, "pengaruh menghafal al-quran terhadap pembentukan karakter peserta didik di roudhotul atfal (ra) jamiatul qurra cimahi," golden age: jurnal ilmiah tumbuh kembang anak usia dini 2, no. 1 (march 31, 2017): 1-15; zulkarnaen zulkarnaen, bustanur bustanur, and zulhaini zulhaini, "pengaruh program tahfidz al-qur'an terhadap prestasi belajar santri/yah pondok pesantren kh. ahmad dahlan," jom ftk uniks (jurnal online mahasiswa ftk uniks) 1, no. 2 (june 29, 2020): 103-8; Marliza Oktapiani, "Tingkat Kecerdasan Spiritual Dan Kemampuan Menghafal Al-Qur'an,” Tahdzib Al-Akhlaq: Jurnal Pendidikan Islam 3, no. 1 (June 10, 2020): 95-108.

${ }^{42}$ Oktapiani, “Tingkat Kecerdasan Spiritual Dan Kemampuan Menghafal Al-Qur'an”; M. Khozin Kharis, “Kontribusi Program Tahfidzul Qur'an Jurusan Agama Dalam Mengembangkan Manajemen Pendidikan Berbasis Pesantren MA Al-Amiriyyah Blokagung Tegalsari Banyuwangi," Jurnal Darussalam: Jurnal Pendidikan, Komunikasi Dan Pemikiran Hukum Islam 8, no. 2 (October 9, 2017): 371-86, https://doi.org/10.30739/darussalam.v8i2.108; Yuliani Rahmi, "Metode Muraja'ah Dalam Menghafal Al-Qur’An Di Pondok Pesantren Al-Mubarok Tahtul Yaman Kota Jambi," Innovatio: Journal for Religious Innovation Studies 19, no. 1 (June 30, 2019): 65-76, https://doi.org/10.30631/innovatio.v19i1.78; Wiwik Hendrawati, Rosidi Rosidi, and Sumar Sumar, “Aplikasi Metode Tasmi' Dan Muraja'ah Dalam Program Tahfidzul Quran Pada Santriwati Di Ma'had Tahfidz Hidayatul Qur'an Desa Puding Besar," LENTERNAL: Learning and Teaching Journal 1, no. 1 (January 22, 2020): 1-8, https://doi.org/10.32923/lenternal.v1i1.1272.
} 
1) Mampu mengosongkan benaknya dari pikiran-pikiran dan teori-teori, atau permasalahanpermasalahan yang sekiranya akan mengganggunya. Mengosongkan pikiran lain yang sekiranya mengganggu dalam proses menghafal merupakan hal yang penting. Dengan kondisi yang seperti ini akan memepermudah dalam proses menghafal al-Qur'an karena benar-benar fokus pada hafalan al-Qur'an.

2) Niat yang ikhlas, niat adalah syarat yang paling penting dan paling utama dalam masalah hafalan al-Qur'an. Sebab, apabila seseorang melaukan sebuah perbuatan tanpa dasar mencari keridhaan Allah semata, maka amalannya hanya akan sia-sia belaka.

3) Izin dari orang tua, wali atau suami. Semua anak yang hendak mencari ilmu atau menghafalkan al-Qur'an, sebaiknya terlebih dahulu meminta izin kepada kedua orang tua dan kepada suami (bagi wanita yang sudah menikah). Sebab, hal itu akan menentukan dan membantu keberhasilan dalam meraih cita-cita untuk menghafalkan al-Qur'an.

4) Tekad yang kuat dan bulat. Tekad yang kuat dan sungguh-sungguh akan mengantar seseorang ke tempat tujuan, dan akan membentengi atau menjadi perisai terhadap kendala-kendala yang mungkin akan datang merintanginya.

5) Sabar, Keteguhan dan kesabaran merupakan faktor-faktor yang sangat penting bagi orang yang sedang dalam proses menghafal al-Qur'an. Hal ini disebabkan karena dalam proses menghafal al-Qur'an akan banyak sekali ditemui berbagai macam kendala.

6) Istiqamah. Maksud dari istiqamah adalah konsisten, yaitu tetap menjaga keajekan dalam menghafal al-Qur'an. Dengan perkataan lain penghafal harus senantiasa menjaga kontinuitas dan efisiensi terhadap waktu untuk menghafal al-Qur'an.

7) Menjauhkan diri dari maksiat dan perbuatan tercela. Perbuatan maksiat dan perbuatan tercela merupakan sesuatu perbuatan yang harus dijauhi bukan saja oleh orang yang sedang menghafal al-Qur'an, tetapi semua kaum muslim umumnya. Karena keduanya mempengaruhi terhadap perkembangan jiwa dan mengusik ketenangan hati, sehingga akan menghancurkan istiqamah dan konseantrasi yang telah terbina dan terlatih sedemikian bagus.

8) Mampu membaca dengan baik. Sebelum penghafal al-Qur'an memulai hafalannya, hendaknya penghafal mampu membaca al-Qur'an dengan baik dan benar, baik dalam Tajwid maupun makharij al-hurufnya, karena hal ini akan mempermudah penghafal untuk melafadzkannya dan menghafalkannya.

9) Berdo'a agar sukses menghafal al-Qur'an.

Terkait dengan adab membaca dan menghafal al-Quran di atas, memang penerapan menghafal al-Qur'an bagi siswa di SDN 05 tadi pada awalnya merupakan iniatif guru PAI untuk mengajak anak mencintai al-Qur'an melalui hafalan surat-surat pendek pada juz Amma (Juz 30). Inisiatif ini akhirnya menjadi program yang terapkan oleh kepala sekolah dengan tujuan agar sekolan umun seperti SD ini, terlihat ada nuansa islamnya. Tentu guru tidak terlalu ketat dan mengatus siswa sesusai dengan teori di atas, seperti, siswa yang belum sama sekali membaca al-Qur'an tetap diikut sertakan dalam program ini. Salah satu cara agar kecintaan tumbuh melalui hafalan tersebut, tentuk tidak berjalan dan berhasil dengan baik jika pihak sekolah tidak melakukan terobosan dengan cara manjalin kerjasama dengan wali siswa. Sebagai contoh, ketika di sekolah si anak dapat dengan lancar menghafal ayat-ayat pendek namun tidak dibiasakan diulang di rumah maka hafalan yang diperoleh di sekolah akan hilang dari hafalan mereka.

Sebab menghafal al-Qur'an berbeda dengan menghafal materi pembelajaran yang lain, karen umat Islam menakini bahwa al-Quran adalah kitab yang suci sebagai wahyu dari yang Maha Suci dan diturunkan kepada manusia yang suci, maka wajar ketika ingin membaca dan menggajinya seorang murid harus diawali dengan membersihan diri baik dari aspek jasmani maupun rohani dan itulah kata kunci yang diterapkan oleh guru PAI di SD 05 Kecamatan Bermani Ulu Kabupaten Rejang Lebong, Bongkulu. 


\section{Penutup}

Bentuk kerja sama Guru SDN 05, Kec. Bermani Ulu, Kab. Rejang Lebong dengan Wali Siswa; menjalin komunikasi satu sama lain, untuk memberikan pengawasan dan bimbingan di rumah, memotivasi siswa dalam bentuk apapun dan bekerja sama mengadakan perlombaan hafalan untuk siswa di sekolah pada hari-hari besar Islam. Kendala yang ditemui oleh guru PAI SDN 02 Lebong Atas antara lain adalah: waktu belajar masih kurang sehingga perlu jam tambahan di luar jam PAI, apalagi program tersebut sifatnya ekstrakulikuler; tingkat pendidikan dan profesi orang tua yang bervariasi sehingga berdampak pada kesibukan orang tua siswa dan kurangnya perhatian kepada anak-anak mereka di rumah untuk melancarkan hafalan ayat-ayat pendek.

\section{Daftar Pustaka}

Abdurahman, Abdurrahman. "Kesadaran Beragama Pada Anak." Jurnal Al-Irsyad: Jurnal Bimbingan Konseling Islam 1, no. 1 (2019): 56-68.

Aflisia, Noza. "Urgensi Bahasa Arab Bagi Hafizh Al-Qur'an." Fokus Jurnal Kajian Keislaman Dan Kemasyarakatan 1, no. 1 (2016): 47-66.

Ansari, Muhammad Iqbal. "Pelaksanaan Karantina Tahfidzh Al-Qur'an 30 Hari Untuk Siswa Sekolah Dasar Dan Madrasah Ibtidaiyah Di Banjarmasin." Muallimuna: Jurnal Madrasah Ibtidaiyah 2, no. 2 (2017): 1-18.

Anwar, Khoirul, and Mufti Hafiyana. "Implementasi Metode ODOA (One Day One Ayat) Dalam Meningkatkan Kemampuan Menghafal Al-Quran." Jurnal Pendidikan Islam Indonesia 2, no. 2 (2018): 181-198.

Apriyanti, Eva, and Hasan Basri. "Pembiasaan Membaca Al-Qur'an di Pondok Al-Ishlah Sendangagung Paciran Lamongan.” Tamaddun 21, no. 1 (2020): 053-066.

Astuti, Yulia Widji. "Gambaran kebiasaan menyikat gigi dan indeks OHI-S pada siswa sekolah dasar." Jurnal teknologi keperawatan 2, no. 1 (2019): 1-33.

Aziz, Jamil Abdul. "Pengaruh Menghafal Al-Quran Terhadap Pembentukan Karakter Peserta Didik Di Roudhotul Atfal (RA) Jamiatul Qurra Cimahi." Golden Age: Jurnal Ilmiah Tumbuh Kembang Anak Usia Dini 2, no. 1 (March 31, 2017): 1-15.

Badruzaman, Dudi. "Metode Tahfidz Al-Qur'an di Pondok Pesantren Miftahul Huda Ii Kabupaten Ciamis." Idea: Jurnal Humaniora 0, no. 0 (October 22, 2019): 245-53. https://doi.org/10.29313/idea.v0i0.4888.

Daheri, Mirzon, and Idi Warsah. "Pendidikan Akhlak: Relasi Antara Sekolah Dengan Keluarga." At-Turats: Jurnal Pemikiran Pendidikan Islam 13, no. 2 (2019): 1-20.

Eka, Besse Tantri. "Penerapan metode jibril dalam Meningkatkan Kemampuan Menghafal Qs. Al-Insyiqoq Ayat 1-25 di Ma'had al-Jami'ah UIN Raden Fatah Palembang (Skripsi).” PhD Thesis, UIN Raden Fatah Palembang, 2016.

Haironi, Adi, ArI Anshori, and M. Ag Muthoifin. "Implementasi Metode Taḥfĩzul Quran Abaq, Sabqi, Manzil Di Marhalah Mutawasithah Dan Tsanawiyah Putri Pondok Pesantren Imam Bukhari Tahun Pelajaran 2010-2014." PhD Thesis, Universitas Muhammadiyah Surakarta, 2016.

Hartono, Hartono. "Pendidikan Karakter Dalam Al Qur'an Pada Kalangan Remaja Di Era Digital.” Al-Bayan: Jurnal Ilmu al-Qur'an Dan Hadist 1, no. 2 (2018): 178-199.

Hasibuan, Zainal Efendi. "Spiritualisasi Pembelajaran dalam Perspektif ISLAM: Membangun Bangsa Berkarakter Di Tengah Krisis Moral Melalui Spritualisasi Pembelajaran Dalam Perspektif Islam.” Darul Ilmi 4, no. 1 (2016). 
Hendrawati, Wiwik, Rosidi Rosidi, and Sumar Sumar. "Aplikasi Metode Tasmi' Dan Muraja'ah Dalam Program Tahfidzul Quran Pada Santriwati Di Ma'had Tahfidz Hidayatul Qur'an Desa Puding Besar." Lenternal: Learning and Teaching Journal 1, no. 1 (January 22, 2020): 1-8. https://doi.org/10.32923/lenternal.v1i1.1272.

Hidayah, Aida. "Metode Tahfidz Al-Qur'an Untuk Anak Usia Dini (Kajian Atas Buku Rahasia Sukses 3 Hafizh Quran Cilik Mengguncang Dunia)." Jurnal Studi Ilmu-Ilmu Al-Qur'an Dan Hadis 18, no. 1 (2018): 51-70.

Imtihana, Aida. "Implementasi Metode Jibril Dalam Pelaksanaan Hafalan Al-Qur'an Di SD Islam Terpadu Ar-Ridho Palembang." Tadrib 2, no. 2 (2016): 179-197.

Kasim, Maryam. "Peningkatan Hasil Belajar Mengartikan Surat-Surat Pendek Melalui Metode Card Sort Mapel Qur'an-Hadits Siswa Kelas V SD Muhammadiyah 16 Semarang Tahun Pelajaran 2015-2016.” PhD Thesis, UIN Walisongo, 2016.

Khaeroni, Cahaya. "Sejarah Al-Qur'an (Uraian Analitis, Kronologis, Dan Naratif Tentang Sejarah Kodifikasi Al-Qur'an)." Historia: Jurnal Program Studi Pendidikan Sejarah 5, no. 2 (2017): 195-206.

Kharis, M. Khozin. “Kontribusi Program Tahfidzul Qur'an Jurusan Agama Dalam Mengembangkan Manajemen Pendidikan Berbasis Pesantren MA Al-Amiriyyah Blokagung Tegalsari Banyuwangi." Jurnal Darussalam: Jurnal Pendidikan, Komunikasi Dan Pemikiran Hukum Islam 8, no. 2 (October 9, 2017): 371-86. https://doi.org/10.30739/darussalam.v8i2.108.

Mayasari, Duma. "Internalisasi Nilai-Nilai Karakter Peserta Didik Dalam Pembelajaran Tahsin Dan Tahfidz Al-Qur'an di MA Tahfizhil Qur'an Yayasan Islamic Centre Sumatera Utara." ANSIRU PAI: Pengembangan Profesi Guru Pendidikan Agama Islam 3, no. 2 (2019): 40-48.

Miles, Matthew B., A. Michael Huberman, and Johnny Saldaña. Qualitative Data Analysis: A Methods Sourcebook. 3rd. Thousand Oaks, CA: Sage, 2014.

Moleong, Lexi J. Methodology of Qualitative Research. Bandung: Remaja Rosda Karya, 2010.

Mundiri, Akmal, and Irma Zahra. "Implementasi Metode STIFIN dalam Meningkatkan Kemampuan Menghafal Al-Qur'an Di Rumah Qur'an STIFIn Paiton Probolinggo.” Jurnal Pendidikan Agama Islam (Journal of Islamic Education Studies) 5, no. 2 (2017): 201-223.

Nasaiah, Rohimah. "Proses Pelaksanaan Pembelajaran Tahfiz Al-Qur'an di Pondok Pesantren Al-Qur'an Harsallakum Kota Bengkulu.” PhD Thesis, IAIN Bengkulu, 2019.

Nurkhaeriyah, Nurkhaeriyah. "Metode Menghafal Al-Qur'an pada Anak Usia Dini di Rumah Tahfidz Qur'an At-Taqwa Kota Cirebon." Jurnal Jendela Bunda Program Studi PGPAUD Universitas Muhammadiyah Cirebon 7, no. 1 (2019): 1-16.

Oktapiani, Marliza. "Tingkat Kecerdasan Spiritual dan Kemampuan Menghafal Al-Qur'an." Tahdzib Al-Akhlaq: Jurnal Pendidikan Islam 3, no. 1 (June 10, 2020): 95-108.

Paulina, Melisa. "Regulasi Diri Mahasiswa UIN Raden Fatah Penghafal Al-Qur'an Di Rumah Tahfidz Yatim Dhuafa Palembang.(Skripsi*)." PhD Thesis, UIN Raden Fatah Palembang, 2020.

Pautina, Amalia R. "Aplikasi Teori Gestalt Dalam Mengatasi Kesulitan Belajar Pada Anak." Tadbir: Jurnal Manajemen Pendidikan Islam 6, no. 1 (2018): 14-28. 
Raharjo, Sabar Budi. "Pendidikan Karakter sebagai Upaya Menciptakan Akhlak Mulia." Jurnal Pendidikan dan Kebudayaan 16, no. 3 (2010): 229-38. https://doi.org/10.24832/jpnk.v16i3.456.

Rahmi, Yuliani. "Metode Muraja'ah dalam Menghafal Al-Qur'an di Pondok Pesantren AlMubarok Tahtul Yaman Kota Jambi." Innovatio: Journal for Religious Innovation Studies 19, no. 1 (June 30, 2019): 65-76. https://doi.org/10.30631/innovatio.v19i1.78.

Retnowati, Yuni. "Metode Pembelajaran Hafalan Surat-Surat Pendek Pada Anak Usia Dini RA Full Day Se-Kabupaten Bantul.” Al-Athfal: Jurnal Pendidikan Anak 5, no. 1 (2019): 101-116.

Ridwan, Wasis, and Ode Moh Man Arfa Ladamay. "Peran Guru Pendidikan Agama Islam Dalam Pembinaan Akhlakul Karimah Peserta Didik di SMA Muhammadiyah 8 Cerme Gresik." Tamaddun 21, no. 1 (April 4, 2020): 067-076. https://doi.org/10.30587/tamaddun.v21i1.1378.

Roulston, Kathryn. "Analysing Interviews." The SAGE Handbook of Qualitative Data Analysis, 2014, 297-312.

Setiawan, Albi Anggito, Johan. Metodologi penelitian kualitatif. CV Jejak (Jejak Publisher), 2018.

Supriadi, Dedi. "Pokoknya Kualitatif: Dasar-Dasar Merancang dan Melakukan Penelitian Kualitatif." Jakarta: PT. Dunia Pustaka Jaya, 2011.

Susianti, Cucu. "Efektivitas Metode Talaqqi Dalam Meningkatkan Kemampuan Menghafal Al-Qur'an Anak Usia Dini." Tunas Siliwangi: Jurnal Program Studi Pendidikan Guru PAUD STKIP Siliwangi Bandung 2, no. 1 (2017): 1-19.

Suwendra, I. Wayan. Metodologi Penelitian Kualitatif Dalam Ilmu Sosial, Pendidikan, Kebudayaan Dan Keagamaan. Nilacakra, 2018.

Suwito, H. "Sistem Menghafal Cepat Al-Quran 40 Hari Untuk 30 Juz (Studi di Ma'had Tahfidz al-Quran di Dawuhan Purbalingga)," 2016.

Taja, Nadri, Dinar Nur Inten, and Arif Hakim. "Upaya Meningkatkan Keterampilan Mengajar Baca Tulis Al-Quran Bagi Guru." Jurnal Obsesi: Jurnal Pendidikan Anak Usia Dini 3, no. 1 (2019): 68-81.

Wiyono, Joko. "Efektivitas Metode Kaidah Daqu di Pendidikan Hafiz SD Daarul Qur'an Semarang." PhD Thesis, UNNES, 2019.

Zaini, Hasan. "Perspektif Alquran Tentang Peningkatan Etos Kerja Dalam Menghadapi Revolusi Industri 4.0 dan Perubahan Sosial 5.0.” Proceeding IAIN Batusangkar 1, no. 1 (2020): 1-18.

Zulkarnaen, Zulkarnaen, Bustanur Bustanur, and Zulhaini Zulhaini. "Pengaruh Program Tahfidz Al-Qur'an Terhadap Prestasi Belajar Santri/yah pondok pesantren kh. Ahmad dahlan." Jom FTK Uniks (Jurnal Online Mahasiswa Ftk Uniks) 1, no. 2 (June 29, 2020): 103-8.

Zunita, Nurma. "Implementasi Adab Hamalatul Qur'an dalam Kitab at-Tibyan Karya Imam an-Nawawi di Ponpes Nurul Qur'an Kajen Margoyoso Pati." PhD Thesis, UIN Walisongo Semarang, 2018. 